\title{
Quality education, social cohesion and active labour market policies. A case study from a Southern European island state
}

\section{Mark Anthony Camilleri', University of Malta, Malta and University of Edinburgh, Scotland.}

How to Cite: Camilleri, M.A. (2020). Quality education, social cohesion and active labour market policies. A case study from a Southern European island state. EuroMed Journal of Management. Forthcoming.

This is a prepublication version.

\begin{abstract}
Societies can benefit from the delivery of inclusive education, lifelong learning as well as from active labour market policies. Therefore, this paper reviews the relevant literature on the provision of quality education for social cohesion. Afterwards, it analyses the latest socioeconomic policies that are being implemented in the smallest European island state of Malta. The findings suggest that the Maltese Government's labour market policies are increasingly targeting vulnerable individuals who are not in employment, education or training, including women and migrant workers, among others. At the same time, the policy makers are striving in their endeavours to attract more students in higher and vocational education to reduce the number of early school leavers. In conclusion, this contribution implies that the pursuit towards continuous improvements in quality education and in social cohesion can create a virtuous cycle of productivity outcomes, including job creation and societal well-being.
\end{abstract}

Keywords: quality education, social inclusion, social cohesion, labour market, Malta, EU2020.

\footnotetext{
${ }^{1}$ Department of Corporate Communication, Faculty of Media and Knowledge Sciences, University of Malta, Malta. Email: mark.a.camilleri@um.edu.mt. The Business School, University of Edinburgh Scotland, UK.
} 


\section{Introduction}

Education can contribute to create a fair and equitable society for all (OECD, 2008; Anderson, 2007). It provides opportunities for social mobility as individuals are rewarded according to their own merit (Mok, 2016; Breen and Jonsson, 2005). Therefore, interventions in educational and employment policies may play a significant role in shaping key performance indicators for the desired social and economic outcomes (Ramsden, 2003). With better education, there may be implications for job creation, competitiveness and prosperity (EU, 2014; OECD, 2012). The United Nations has also recognised the importance of delivering quality education; it included it as a standalone Sustainable Development Goal (i.e. SDG4) (Camilleri, 2020; Vladimirova and Le Blanc, 2016; UNSDG4, 2015). Notwithstanding, academia often attempt to explore the link between education and economic growth (Gupta and Vegelin, 2016; Gradstein and Justman, 2002; Green, Preston, and Sabates, 2003; Thorbecke and Charumilind, 2002).

This paper presents a critical review of relevant theoretical underpinnings and regulatory guidelines on the link between quality education and cohesive societies. Afterwards, it sheds light on education and labour market policies in the Maltese context. The findings of this research suggests that Malta is responding to the European Union's (EU 2020) recommendations; to reduce the number of early school leavers, to entice more individuals to pursue higher and vocational education, and to alleviate poverty and social exclusion through job opportunities, among other targets (EU, 2014). This contribution posits that the smallest EU state is raising awareness on the importance of ongoing education and training for all citizens. It explains how the Maltese government is addressing the skill gaps and mismatches in its labour market, as the country is introducing (or has introduced) a number of policies as well as productivity measures to improve its citizens' socio-economic performance. 


\subsection{Setting the scene of the research context}

The flagship initiatives of the Europe 2020 strategy, including its 'Social Investment Package', have provided guidance to Member States to modernise their welfare systems (EU, 2010a,b). Currently, there are millions of Europeans who are still not contributing in their labour market. According to EuroStat (2018), the at-risk-of-poverty rate in the EU-28 has reached $17.3 \%$ in 2016. The latest rates suggest that the females are at a higher risk of poverty than their male counterparts. The differences in at-risk-of-poverty rates were wider when the population is classified according to activity status. Half of the unemployed and around one in seven $(13.8 \%)$ retired persons within the EU-28 were at-risk-of-poverty in 2016. Conversely, those in employment were far less likely to be at-risk-of-poverty (there was an average of $9.6 \%$ across the whole of the EU-28 in 2016). One out of four individuals who live alone (i.e. single person households) are most likely to be at risk of poverty. Moreover, the at-risk-of-poverty rate was even higher for single persons with dependent children. In this case, there were a number of exceptions where the rate was higher for households composed of two adults with three or more children (EuroStat, 2018). In this light, the fight against poverty and social exclusion is at the heart of the Europe's 2020 strategy for smart, sustainable and inclusive growth (Pasimeni and Pasimeni, 2015; Copeland and Daly, 2012).

According to the EU's (2019) country report, Malta is performing relatively well when compared to the other European states' social scoreboard indicators. Malta has achieved its targets on employment and tertiary education. However, it is lagging behind other European nations in terms of raising its research and development expenditure and reducing early school leaving, among other issues. It may appear that Malta is addressing its poverty and social exclusion. However, it is experiencing a large inflow of foreigners who are creating integration challenges amongst the locals. The increase in the population is putting pressure on the 
provision of services, including education, housing, health and long-term care. Malta's overall employment rate is well above the EU average and its long-term unemployment rates are low. Yet, there is still a gender employment gap and pay gap in Malta as the gainfully occupied females are earning less than their male counterparts. Notwithstanding, the employment rate of older workers is particularly low. In addition, the country has a high proportion of early school leavers who do not possess relevant skills and competencies to contribute to the labour market This discourse leads to this paper's underlying research question:

\subsection{Focused research question}

'How can the education, social welfare and employment policies improve the social fabric as well as the economic performance in Malta?'

\section{The provision of quality education for cohesive societies}

The fight against poverty is a central component of social cohesion (Flecha, 2014; Ferrera, Matsaganis and Sacchi, 2002). In many EU countries, the wealthy households are significantly in a much better position than middle-class and poor households. Moreover, unequal results in education are increasingly being tolerated as long as they are proportionate to the different characteristics of pupils at the start of their courses (Souto-Otero and Whitworth, 2006). Under this principle, a notion of 'objective merit', is typically measured through examination scores. This system has guided the progress of individuals through several educational systems. Therefore, the financial support to individuals from less privileged backgrounds is permissible according to this principle. The emphasis of this principle is on the young individuals' access to courses rather than on the structure or quality of these courses (Souto-Otero and Whitworth, 2006). 
Green et al. (2003) believed that there is little clarity in the policy discussions on the relationship between education and social cohesion. Whereas, Heyneman (2000) argued that social cohesion had significant economic benefits particularly in western societies where public education has been one of the main contributors to social cohesion. Gradstein and Justman (2000) had reported that uniform schooling reduced re-distributional conflict among distinct social groups. They emphasised the central role of human capital as they explained how education contributed to increase economic growth. Gradstein and Justman (2000) examined the implications of experiencing endogenous growth where education plays the dual role of building human capital and determining social orientation. However, they also held that these two dimensions may inevitably interact through the adverse effect of social polarisation on the productivity of human capital.

Significant investments have already been made across the globe to raise competencies that help improve social outcomes. The individuals' competences are known to affect educational and labour market success. For example, the fourth United Nations' (UN) Sustainable Development Goal (SDG4) and its 10 targets represent an ambitious and universal agenda to develop the individuals' skills for better lives. Five of the 10 targets are concerned with improving the quality of education for individual children, young people and adults, and to provide them with more competences for the labour market. During the last few decades; major progress has been made towards increasing access to education at all levels, in order to instil relevant knowledge and skills for decent work and global citizenship (UNSDG4, 2015). SDG4 aims to eliminate gender disparities as all students should have equal access to all levels of education (UNSDG4, 2015). A pertinent literature review suggests that most of the other SDGs are also linked with education (Vladimirova and Le Blanc, 2016) and social cohesion (Gupta and Vegelin, 2016). Notwithstanding, the promotion of quality education had re-emerged as an important policy objective across many countries, particularly during the past decade. For 
instance, the aims of Europe's 2020 Strategy (that was launched in 2010) were intended to improve the EU's competitiveness and productivity levels that underpin the market economy (EU, 2010a,b). This strategy identified three priorities as the main pillars: Smart growthdeveloping an economy based on knowledge and innovation; Sustainable growth-promoting a more resource efficient, greener and more competitive economy; and Inclusive growthfostering a high-employment economy delivering economic, social and territorial cohesion (Pasimeni and Pasimeni, 2015). Therefore, this European strategy has a strong focus on employment creation, skills and labour market reform. It explicitly targets poverty reduction and exclusion (Ferrera et al., 2002).

Moreover, one of the prerogatives of Europe 2020 is to reduce the share of early school leavers to less than $10 \%$ (EU, 2014). In a way, these ambitious targets are also consonant with the United Nations very own SDGs (UNSDG4, 2015). These goals have the potential to become a powerful political vision that can support the urgently needed global transition to a shared and long-lasting prosperity (Hajer, Nilsson, Raworth, Bakker, Berkhout, de Boer, Rockström, Ludwig and Kok, 2015). Europa 2020 aims to increase the employment rates as it wants to raise the quality of jobs, especially for the disadvantaged groups in society, including; women, young adults and adolescents, disabled individuals and older workers. It is also its intention to integrate migrants in the labour force. This calls for a need to anticipate and manage change by investing in skills and training whilst modernising labour markets and welfare systems (Polidano et al., 2015). Economic development is closely linked to the capacity to create, retain and attract human capital (Halpern, 2013; Forrest and Kearns, 2001). The countries' economic growth is also correlated to the quality of education, training and life-long learning opportunities (Kilpatrick, Field and Falk, 2003). However, OECD's Programme for 
International Student Assessment (PISA ${ }^{2}$ ), as well as its adult version, the Programme for the International Assessment of Adult Competencies (PIAAC) suggest that although many countries may experience high attendances at school; only a proportion of pupils will eventually achieve adequate and sufficient levels of proficiency when they complete their compulsory, secondary education. This finding does not augur well for economic, social and sustainable development. Hence, bolder efforts are required to make even greater strides to deliver quality education for all.

Educators may feel over-burdened by pressures to meet the regulatory institutions' performance criteria that define success, including; raising student performance in high-stakes tests, improving the quality of curricula and instruction, and dealing with children from diverse cultural and linguistic backgrounds (Ramsden, 2003). Some academic commentators argue that quality education may become more affordable across the population, and schooling may become a strong leveller of opportunities (Camilleri and Camilleri, 2016). Consequently, this may ultimately bring better prospects for upward social mobility (Goldthorpe and Jackson, 2007). 'A cohesive society works towards the well-being of all its members, fights exclusion and marginalisation, creates a sense of belonging, promotes trust, and offers its members the opportunity for upward mobility' (OECD, 2011, p. 17). Education may well reduce any inequalities in society by fostering cognitive, interpersonal and emotional skills as well as promoting healthy lifestyles, participatory practices and norms (Jackson, 2009). It is important to realise that certain instruments that reduce opportunity costs of continued education can possibly improve attainment levels (OECD, 2012; Breen and Jonsson, 2005). Therefore, lowering the cost of schooling may encourage the enrolment in higher education (Christensen and Eyring, 2011). This argumentation calls for ensuring policy coherence across sectors and

\footnotetext{
${ }^{2}$ PISA is the world's most widely used global metric to measure the quality of learning outcomes, as well as its adult version
} 
stages of education levels as well as an active engagement in collaborative agreements with business and industry. This underlines the importance of taking a holistic approach with all stakeholders (Camilleri, 2015). Governments should promote strong linkages horizontally (i.e. across the government ministries), vertically (i.e. across central, regional and local levels of government) and dynamically (i.e. across different levels) (Estol, Camilleri and Font, 2018; OECD, 2010, p. 207). Policy coherence on the delivery of an inclusive, quality education, lifelong learning as well as the implementation of active labour market policies would effectively result in the countries' economic growth and competitiveness (Camilleri, 2020; Gradstein and Justman, 2002).

\subsection{Social inclusion}

Social inclusiveness has its roots in human rights, inequality, redistribution, entitlements and capabilities (Gupta and Vegelin, 2016). It involves empowering the poorest strata in society through investments in human capital, to enhance the individuals' participation in the labour market (EU, 2013a; Forrest and Kearns, 2001). Social inclusion is non-discriminatory and is age-, gender-, caste-, sect- and creed- sensitive in terms of income, assets and employment opportunities (Liasidou, 2014; Humphries, 2004). Education has the potential to bring social inclusion through civic and social engagement (Camilleri, 2016a, 2016b; Putnam, 2001; 1995). How children are schooled will also have an impact on their sense of belonging to a society. The schooling experience itself impacts social cohesion, as it shapes and transmits common values that underpin social capital and inclusion (OECD, 2012). Green et al. (2003) had clearly distinguished between social capital and societal cohesion. They argued that quality education

acts in differential ways on both concepts. Green et al.'s (2003) 'distributional model' shed light on the relationship between the equality of educational outcomes and the various measures of social cohesion. 
Galston (2001) indicated that school-based efforts to form active citizens may not be successful if the children's families and their local communities do not provide good opportunities for them to engage in civic activities. Similarly, Putnam (2001) argued that open classroom environments, classes that require practical involvement in social matters as well as school ethos that promote active citizenship can be conducive to build stronger civic participation, from a tender age. These efforts are most likely to be successful when family and community environments are aligned together with the institutional efforts made by policy makers. The children's well-being and their social progress are more likely to work when their home and community environments are synchronised with what the children experience when they are at school (OECD, 2010). In addition, quality education may create an inclusive schooling environment that nurtures social cohesive values towards the entire community (Camilleri, 2016b; Flecha, 2014).

Education can become more inclusive toward the most vulnerable groups in society. The formulation of specific policies and measures for social equity can foster equal access to education for all boys and girls, hailing from diverse backgrounds. Efforts to close the gender gap in education may help to break the intergenerational transmission of poverty (Jacob, 2002). Therefore, the policy makers are instrumental in emphasising the delivery of inclusive curricula and teaching practices that foster diversity in schools as well as in society (Ambe, 2006). An increased awareness among children on diversity issues would improve the integration of minorities in education, and eventually in the labour market. The inclusive schooling systems tend to perform better in terms of learning outcomes when compared to the segmented ones (Ainscow, 1997). 
A significant fraction of children, mostly from disadvantaged households, are usually deprived of access to quality education (Liasidou, 2014; Currie, 2001). Therefore, education policy may help to address the skills' deficits of children who have missed the opportunity to develop their basic competencies, earlier on in their life. Perhaps, the governments should adopt a more pragmatic stance to social equity issues in order to maximise the representation, participation and recognition of the disadvantaged groups in society (Camilleri, 2017; Raffo and Gunter, 2008; Humphries, 2004).

\subsection{Social equality}

Gradstein and Justman (2002) maintained that education is a socialising force as it instils civic virtues from an early age. Therefore, quality education may facilitate the interaction between the various members of society who differ in their backgrounds. As such, education has often played a key role in forging national identities and in establishing centralised governments. However, the coercive, centralised schooling may result in less welfare than decentralised education (Gradstein and Justman, 2002). The contribution of quality education to economic growth are also conditioned by cultural and religious divisions (Spring, 2017; Gradstein and Justman, 2002). The distribution of ethnic groups and the social distance between them can affect this relationship (Gradstein and Justman, 2002). Hence, the design and assessment of educational reforms should take into account their impact on the socialising role of education.

Green et al. (2003) posited that education effects socialisation as the schools' ethos and their curricula are conducive to social cohesion. The provision of quality education can lead to improvements to the individuals' communication and transferable skills, as it facilitates their cross-cultural understanding and civic participation. Thorbecke and Charumilind's (2002) study had indicated a strong correlation between the skills' distribution and income inequality 
across countries. They found a highly negative and significant relationship between educational inequality / income inequality with social cohesion. In a similar vein, Green et al. (2003) reported that educational inequality exercised a significant, negative effect on social cohesion; whilst quality education was related to social cohesion. The former generates equal opportunities, in terms of income and cultural capital amongst different people.

Previously, Knack and Keefer's (1997) study had shown that trust and civic norms are stronger in advanced economies that can offer quality education and higher incomes. In a similar vein, Green et al.'s (2003) empirical studies had proved that social cohesion and quality education are highly sensitive to inequality as well. Perhaps more attention ought to be placed on the development of shared or cooperative values and on the attenuation of inequalities in educational outcomes. Green et al. (2003) hinted that many Anglophone countries were placing more stress on raising mean levels of achievement rather than on reducing inequalities. The provision of quality education may have led to significant benefits to the labour market and to the desired economic outcomes (Brown, Hesketh, and Williams, 2003). However, when it comes to promoting social cohesion, there is clearly a case for prioritising the social inclusion of the most vulnerable people (EU, 2013a). For instance, Beauchamp-Pryor (2012) maintained that the disabled people need to be involved in future policy development. She suggested that barriers such as power sharing, as well as the traditional ideologies are increasingly being challenged by the disabled voices that want to become more active in the labour market.

The regulatory institutions' responsibility is to tackle the inequality that polarises their societies (EURES, 2013). Greater income inequality stifles upward social mobility, making it harder for talented and hard-working people to get the rewards they deserve (Goldthorpe and Jackson, 2007). Generally, social equity seems to be higher in countries where income inequalities are 
relatively low. The processes of social mobility from one generation to the next, and from the career beginnings to occupational destinations often reflect the different dynamics of the institutional policies. The following sections critically analyse, the educational and employment policies in Malta:

\section{Policies in Education}

The EU (2013b) had recommended that Malta ought to take bold decisions to reduce its high rate of early school leavers. On 5 April 2013, the (Maltese) Ministry for Education and Employment has launched an 'Early School Leaving Strategy' which was aimed to reduce the number of students who leave school at an early age, and to motivate students to pursue their studies at tertiary levels. In 2016, Malta had one of the highest rates of young school leavers $(19.6 \%)$ within the European context (EU, 2018). This rate is considerably higher for males than for females, where the gender gap is 7.3pps. Therefore, it may prove difficult for Malta to reach the Europa 2020 target to lower its secondary school leavers rate to $10 \%$. Nevertheless, Malta has and is still intensifying its outreach to the young people who leave school with few skills and competences. The smallest EU country has introduced preventative measures against student drop-outs from the education system, including; the implementation of the 'National Curriculum Framework'; more VET opportunities in compulsory education; it strengthened the existent 'Validation of Informal' and 'Non-formal Learning' and developed new forms of teaching and learning, such as 'e-Learning'. Other interventions of the Maltese policy makers involved; forging collaborative relationships among stakeholders, including parents and teachers, in order to address the needs of vulnerable groups of students who were at risk of leaving their school at a very young age. Yet, EU (2018) indicated that the ESL figures are even higher among the disabled individuals. In 2015 this figure was $39.5 \%$ in Malta, whilst the EU average was $22 \%$ (EU, 2018). 
The OECD's Programme for International Student Assessment (PISA) that measures the basic skills' attainment among young individuals indicated that the Maltese students' participation in vocational education and training (VET) remains far below the EU average. However, the employment rate for VET graduates has risen in Malta. The employment rate for the Maltese VET graduates was one of the highest in the EU in 2016 (96.2 \% against $75 \%$ in the EU) (EU, 2018).

In Malta, the tertiary educational attainment rates are still below the EU average; although these figures have risen steadily, in the past years (EU, 2018; NCF, 2012). Notwithstanding, the employment rate (97\%) for recent tertiary graduates has increased by almost 4pps (in Malta), between 2013 and 2015. This is one of the highest figures within the EU; reflecting the demand for highly educated and skilled labour in the smallest EU state. EU (2018) suggests that adequate measures are currently being undertaken, including: ongoing career guidance, retraining and up-skilling of employees in the shrinking economic sectors. However, the adults' participation in continuous professional development and training remains relatively low in Malta.

The Maltese Ministry for Education and Employment has drafted coherent strategies to enhance the lifelong learning opportunities from early childhood education to adult learning (MEE, 2012; 2014). The framework for the (Maltese) Education Strategy for 2014-2024 comprised four goals: (i) Improve the educational outcomes of boys and girls in literacy, numeracy, and science and technology competence. (ii) Support educational achievement of children at-risk-of-poverty and from low socio-economic status, whilst reducing the relatively high incidence of early school-leavers. (iii) Increase participation in lifelong learning, and (iv) Raise levels of student retainment and attainment in further, vocational, and tertiary education 
and training. MEE (2014) articulated the Strategic Pillars for policy development, that comprised; (i) The Governance of Education Organisations, (ii) The Social Dimension, (iii) International Dimension, (iv) The Provision of Quality Education, (v) The Student Focus, and (vi) Strategic Innovation.

\section{Active labour market policies}

Malta is also supporting low-skilled individuals to improve their employability prospects (EU, 2018). The Jobs Plus, formerly known as Employment and Training Corporation (ETC) has made good use of the European Social Funds (ESF) to address the challenge of skill gaps and mismatches in the labour market (EU, 2013b). Similarly, the vocational institution in Malta, namely; Malta College of Arts, Sciences and Technology (MCAST) has benefited from seven ESF projects (during the period between 2008 and 2015) (ESF, 2009). MCAST is playing a critical role with new, industry-related, vocational courses which are relevant to many groups of students, hailing from different socio-economic backgrounds. Moreover, the Maltese government has made use of the ESF funds to open LEAP centres in different locations around the island. This initiative was part of the country's National Strategic Policy for Poverty Reduction and for Social Inclusion. LEAP's mission is to create occupational opportunities for disadvantaged groups and households which are (or are often) at risk of poverty. LEAP's target groups include; single parents, people with disabilities, ex-offenders, migrants and the working poor, amongst others. These segments in society are considered vulnerable or disadvantaged when compared to other citizens. This programme identifies inactive, jobless individuals and facilitates their access to employment.

Notwithstanding, there are other active labour market policies, including the in-work benefits as well as benefit tapering that support individuals to return to work. Other initiatives encourage 
long-term, unemployed women to work by providing income tax rebates. Such measures are targeting vulnerable people who are neither in education, employment nor training. They contribute to improve the economy and to foster social cohesion, by reducing unemployment and poverty.

However, despite these labour market policies, the females' employment rates are still relatively low for those women who are over 30 years of age; whilst the employment rate for men continues to rise or remains stable above the age of 30 (EU, 2018). The Maltese government has encouraged more individuals, including women, to return to work; through the provision of free child-care centres (Camilleri and Camilleri, 2016). The families who opted to send their children to private childcare facilities started benefiting from an income tax deduction of $€ 2,000$ on childcare centre fees (EU, 2013b). Moreover, since October 2009, the Foundation for Educational Service (FES) has offered an after-school service for elder children. This service is being catered for within the same school structures to support those parents who are either in employment or in higher (or vocational) education. Therefore, the schools' infrastructures are utilised after their regular hours. This service runs throughout the scholastic year for school children, aged between 3 and 16 years old (EU, 2013b). Table 1. presents a summary of the socio-economic metrics that assess the performance of the education and labour market policies in Malta. 
Table 1. Social Scoreboard for Malta (against the $E U$ average)

\begin{tabular}{|c|c|c|}
\hline & Metrics & Malta \\
\hline \multirow{5}{*}{$\begin{array}{l}\text { Equal opportunities } \\
\text { and access to the } \\
\text { labour market }\end{array}$} & Early school leavers (ESL) & $\begin{array}{l}\text { Weak but } \\
\text { improving }\end{array}$ \\
\hline & Gender employment gap & $\begin{array}{l}\text { Weak but } \\
\text { improving }\end{array}$ \\
\hline & $\begin{array}{l}\text { Youth Not in Education, } \\
\text { Employment and Training (NEET) }\end{array}$ & On average \\
\hline & Wage gaps (income quintile ratio) & $\begin{array}{l}\text { Better than } \\
\text { average }\end{array}$ \\
\hline & $\begin{array}{l}\text { At risk of poverty or social } \\
\text { exclusion }\end{array}$ & $\begin{array}{c}\text { Better than } \\
\text { average }\end{array}$ \\
\hline \multirow{4}{*}{$\begin{array}{l}\text { Dynamic labour } \\
\text { markets and fair } \\
\text { working conditions }\end{array}$} & $\begin{array}{l}\text { Employment rate (\% of population } \\
\text { aged } 20-64)\end{array}$ & On average \\
\hline & $\begin{array}{l}\text { Net earnings of a full-time single } \\
\text { worker earning average wage }\end{array}$ & On average \\
\hline & $\begin{array}{l}\text { Unemployment rate (\% population } \\
\text { aged } 15-74)\end{array}$ & $\begin{array}{c}\text { Better than } \\
\text { average }\end{array}$ \\
\hline & $\begin{array}{l}\text { Long term unemployment rate (\% } \\
\text { population aged } 15-74)\end{array}$ & $\begin{array}{l}\text { Better than } \\
\text { average }\end{array}$ \\
\hline \multirow[t]{4}{*}{$\begin{array}{l}\text { Social protection } \\
\text { and inclusion }\end{array}$} & $\begin{array}{l}\text { Impact of social transfers (other } \\
\text { than pensions) on poverty reduction }\end{array}$ & On average \\
\hline & $\begin{array}{l}\text { Children less than } 3 \text { years in } \\
\text { childcare }\end{array}$ & $\begin{array}{l}\text { Better than } \\
\text { average }\end{array}$ \\
\hline & $\begin{array}{l}\text { Self-reported unmet need for } \\
\text { medical care }\end{array}$ & $\begin{array}{c}\text { Better than } \\
\text { average }\end{array}$ \\
\hline & Individuals' level of digital skills & $\begin{array}{c}\text { Better than } \\
\text { average }\end{array}$ \\
\hline
\end{tabular}

(Adapted from EU, 2019) 


\section{Discussion and Conclusions}

This paper critically reviewed the relevant literature that raised awareness on the importance of inclusive, quality education. It explained that the education, social welfare and employment policies can foster social cohesion and economic growth. An indispensable requirement for social cohesion is the eradication of poverty, in all of its forms and dimensions. This research suggests that the pursuit towards continuous improvements in realms of quality education and societal progress can create a virtuous cycle of productivity outcomes and economic growth. This contribution is not policy prescriptive. It has merely provided an overview of the policy initiatives that can impact on the socio-economic development of Malta, within the European Union context.

The EU country report found that the employment rate is rising, and the jobless figures are decreasing in Malta. EU (2018) also noted shortcomings in the realms of the Maltese education system. The educational outcomes remain strongly linked to the individuals' socio-economic background. The smallest island state needs to improve the basic skills of its young citizens, and it should continue to reduce the number of early school leavers. At the same time, more Maltese students need to further their studies in higher education. Malta ought to reduce the poverty levels of the most vulnerable groups in society, as this leads to their social exclusion. The single-earner households and the low-skilled employees face substantial poverty risks (EU, 2018). Furthermore, there are pockets among the foreign population, particularly, the non-EU migrants who are facing a high risk of poverty, despite Malta's thriving economy. On the other hand, Malta has improved its labour market. Its 'Make Work Pay' policies, including the inwork benefits, benefit tapering that support individuals to return to work, as well as other measures, including the provision of free child care, among others, are incentivising many individuals, including young women, to return to work. Nevertheless, the Maltese government 
should continue to address its high gender employment gap; increase the participation of vulnerable individuals, including those with a disability. In these last few years more migrants, hailing from EU and non-EU countries are increasingly contributing in the Maltese labour market as the country is experiencing skill shortages, across all levels (EU, 2018).

In conclusion, the EU2020 strategy and its targets are aimed at creating the right conditions for smart, sustainable and inclusive growth in the European context. In a nutshell, this paper suggests that educational and active labour market policies, including; the 'Make Work Pay' initiatives like; benefit tapering, in-work benefits, tax rebates, free childcare facilities are supporting individuals to pursue their studies in vocational or higher education, or to return in employment. Moreover, it explained that employers can be incentivised to support the most vulnerable groups in society, including the migrants and the disabled persons, who would otherwise risk social exclusion.

The ongoing reforms in education ought to be founded on social inclusion and equity principles (Camilleri, 2018), as well-laid out curricula are capable of successfully reducing the early school leavers. Whilst developing the full potential of lifelong learners (UNSDG04, 2015; Kilpatrick et al., 2003). The provision of quality education has introduced certain mechanisms that equip our citizens with the relevant knowledge, skills and competences in order to address the skill gaps in the labour market. Active employment policies are required to help job seekers find work and to support employed individuals to advance in their career through life-long learning opportunities.

\section{References}

Ainscow, M. (1997) 'Towards inclusive schooling', British Journal of Special Education, Vol. 24, pp. 3-6. 
Ambe, E. B. (2006) 'Fostering multicultural appreciation in pre-service teachers through multicultural curricular transformation', Teaching and Teacher Education, Vol. 22, pp. 690699.

Anderson, E. (2007) 'Fair opportunity in education: A democratic equality perspective', Ethics, Vol. 117, No. 4, pp. 595-622.

Beauchamp-Pryor, K. (2012) 'From absent to active voices: Securing disability equality within higher education', International Journal of Inclusive Education, Vol. 16, pp. 283-295.

Breen, R. and Jonsson, J. O. (2005) 'Inequality of opportunity in comparative perspective: Recent research on educational attainment and social mobility', Annual Review of Sociology, Vol. 31, pp. 223-243.

Brown, P., Hesketh, A. and Williams, S. (2003) 'Employability in a knowledge-driven economy', Journal of Education and Work, Vol. 16, pp. 107-126.

Camilleri, M. A. (2015) 'Valuing stakeholder engagement and sustainability reporting', Corporate Reputation Review, Vol. 18, No. 3, pp. 210-222.

Camilleri, M. A. (2016a) 'Corporate sustainability and responsibility toward education', Journal of Global Responsibility, Vol. 7, No. 1, pp. 56-71.

Camilleri, M. A. (2016b) 'Reconceiving corporate social responsibility for business and educational outcomes', Cogent Business \& Management, Vol. 3, No. 1, pp. 1-14.

Camilleri, M.A. and Camilleri, A. (2016) 'Education and social cohesion for economic growth', International Journal of Leadership in Education, Vol. 19, No. 5, pp. 617-631.

Camilleri, M. A. (2017) 'Corporate sustainability and responsibility: creating value for business, society and the environment', Asian Journal of Sustainability and Social Responsibility, Vol. 2, No. 1, pp. 59-74.

Camilleri, M. A. (2018) 'Theoretical insights on integrated reporting: The inclusion of nonfinancial capitals in corporate disclosures', Corporate Communications: An International Journal, Vol. 23 No. 4, pp. 567-581.

Camilleri, M. A., \& Camilleri, A. C. (2020) 'The Sustainable Development Goal on Quality Education', In The Future of the UN Sustainable Development Goals (pp. 261-277). Springer, Cham.

Christensen, C. M. and Eyring, H. J. (2011) 'The innovative university: Changing the DNA of higher education from the inside out', San Francisco, USA: John Wiley and Sons.

Copeland, P. and Daly, M. (2012) 'Varieties of poverty reduction: Inserting the poverty and social exclusion target into Europe 2020', Journal of European Social Policy, Vol. 22, pp. 273-287.

Currie, J. (2001) 'Early childhood education programs', Journal of Economic Perspectives, Vol. 15, pp. 213-238. 
ESF (2009) 'Ex post evaluation of the 2000-2006 ESF support to the open method of coordination in social protection and social inclusion VC/2008/0211', [Online] http://ec.europa.eu/social/BlobServlet?docId=4942andlangId=en [Accessed 14 Nov. 2019].

Estol, J., Camilleri, M. and Font, X. (2018) 'European Union Tourism Policy: An Institutional Theory Critical Discourse Analysis', Tourism Review, Vol. 73, No. 3, pp.421431.

EU (2006) 'European Union: Lifelong learning programme (2007-13)', [Online] http://europa.eu/legislation_summaries/education_training_youth/general_framework/c11082 _en.htm [Accessed 20 Nov. 2019].

EU (2010a) 'European Union: European platform against poverty and social exclusion', [Online] http://ec.europa.eu/social/main.jsp?catId=961 [Accessed 9 Nov. 2019].

EU (2010b) 'European Union: Social protection and social inclusion', [Online] http://ec.europa.eu/social/main.jsp?catId=750 [Accessed 10 Nov. 2019].

EU (2013a) 'European Union: What is social inclusion? European Youth Portal' [Online] http://europa.eu/youth/article/what-social-inclusion-1_en [Accessed 10 Nov. 2019].

EU (2013b) 'European Union: Malta's National Reform Programme under the Europe 2020 Strategy', [Online] http://ec.europa.eu/europe2020/pdf/nd/nrp2013_malta_en.pdf [Accessed 11 Nov. 2019].

EU (2014) 'Europe2020 Targets', European Commission, Brussels, Belgium. [Online] https://ec.europa.eu/info/business-economy-euro/economic-and-fiscal-policycoordination/eu-economic-governance-monitoring-prevention-correction/europeansemester/framework/europe-2020-strategy_en [Accessed 09 Nov. 2019].

EU (2018) 'Country Report Malta 2018', [Online] https://ec.europa.eu/info/sites/info/files/2018-european-semester-country-report-malta-en.pdf [Accessed 11 Nov. 2019].

EU (2019) 'Country Report Malta 2019', [Online] https://ec.europa.eu/info/sites/info/files/file_import/2019-european-semester-country-reportmalta_en.pdf (Accessed 12 Nov. 2019).

EURES (2013) 'The European jobs network: Working conditions', [Online] https://www.eures.com.mt/EuresMalta/Main/Page.aspx?pageid=WorkingConditions (Accessed 11 Nov. 2019).

Eurostat (2018) 'Income Poverty Statistics', [Online] https://ec.europa.eu/eurostat/statisticsexplained/index.php/Income_poverty_statistics\#At-risk-of-poverty_rate_and_threshold (Accessed 12 Nov. 2019).

Ferrera, M., Matsaganis, M. and Sacchi, S. (2002) 'Open coordination against poverty: the new EU social inclusion process', Journal of European Social Policy, Vol. 12, No. 3, pp. 227-239. 
Flecha, R. (2014) 'Successful educational actions for inclusion and social cohesion in Europe', Cham, Switzerland: Springer.

Forrest, R., and Kearns, A. (2001) 'Social cohesion, social capital and the neighbourhood', Urban studies, Vol. 38, No. 12, pp. 2125-2143.

Galston, W. A. (2001) 'Political knowledge, political engagement, and civic education', Annual Review of Political Science, Vol. 4, pp. 217-234.

Goldthorpe, J. H. and Jackson, M. (2007) 'Intergenerational class mobility in contemporary Britain: Political concerns and empirical findings', The British Journal of Sociology, Vol. 58, pp. 525-546.

Gradstein, M. and Justman, M. (2000) 'Human capital, social capital, and public schooling', European Economic Review, Vol. 44, pp. 879-890.

Gradstein, M. and Justman, M. (2002) 'Education, social cohesion, and economic growth', American Economic Review, Vol. 92, pp. 1192-1204.

Green, A., Preston, J. and Sabates, R. (2003) 'Education, equality and social cohesion: A distributional approach', Compare, Vol. 33, pp. 453-470.

Gupta, J. and Vegelin, C. (2016) 'Sustainable development goals and inclusive development', International Environmental Agreements: Politics, Law and Economics, Vol. 16, No. 3, pp 433-448.

Halpern, L. (2013) 'Trade and firms in transition', In P. Hare and G. Turley (Eds.), Handbook of the economics and political economy of transition (pp. 275-283). London, UK: Routledge.

Hajer, M., Nilsson, M., Raworth, K., Bakker, P., Berkhout, F., de Boer, Y. and Kok, M. (2015) 'Beyond cockpit-ism: Four insights to enhance the transformative potential of the sustainable development goals', Sustainability, Vol. 7, No. 2, pp. 1651-1660.

Jackson, M. (2009) 'Disadvantaged through discrimination? The role of employers in social stratification', The British Journal of Sociology, Vol. 60, pp. 669-692.

Jacob, B. A. (2002) 'Where the boys aren't: Non-cognitive skills, returns to school and the gender gap in higher education', Economics of Education Review, Vol. 21, pp. 589-598.

Heyneman, S. P. (2000) 'From the party/state to multi-ethnic democracy: Education and social cohesion in Europe and Central Asia', Educational Evaluation and Policy Analysis, Vol. 22, pp. 173-191.

Humphries, B. (2004) 'An unacceptable role for social work: Implementing immigration policy’, British Journal of Social Work, Vol. 34, No. 1, pp. 93-107.

Kilpatrick, S., Field, J. and Falk, I. (2003) 'Social capital: An analytical tool for exploring lifelong learning and community development', British Educational Research Journal, Vol. 29, No. 3, pp. 417-433. 
Knack, S. and Keefer, P. (1997) 'Does social capital have an economic payoff? A crosscountry investigation', The Quarterly Journal of Economics, Vol. 112, pp. 1251-1288.

Liasidou, A. (2014) 'Critical disability studies and socially just change in higher education', British Journal of Special Education, Vol. 41, No. 2, pp. 120-135.

MEE (2012) 'Early school leaving strategy', Ministry of Education and Employment, Floriana, Malta. [Online] https://skydrive.live.com/view.aspx?resid=BC90B040426DF81B!268andithint=file\%2c.pdfa ndapp=WordPdfandwd=2andauthkey=!AJFSva7m0INh-Yg (Accessed 11 Nov. 2019).

MEE (2014) 'Framework for the Education Strategy in Malta. 2014-2024. Ministry of Education and Employment', Floriana, Malta. [Online] https://education.gov.mt/en/resources/Documents/Policy\%20Documents\%202014/BOOKLE T\%20ESM\%202014-2024\%20ENG\%2019-02.pdf (Accessed 11 Nov. 2019).

Mok, K.H. (2016) 'Massification of higher education, graduate employment and social mobility in the Greater China region', British Journal of Sociology of Education, Vol. 37 No. 1, pp. 51-71.

NCF (2012) 'A national curriculum framework for all', [Online] https://curriculum.gov.mt/en/Resources/The-NCF/Pages/default.spx (Accessed 11 Nov. 2019).

OECD (2008) 'Organisation for economic cooperation and development: Ten steps to equity in education', [Online] http://www.oecd.org/edu/school/39989494.pdf (Accessed 11 Nov. 2019).

OECD (2010) 'Organisation for economic cooperation and development: Improving health and social cohesion through education', [Online]

http://www.oecd.org/edu/ceri/improvinghealthandsocialcohesionthrougheducation.htm (Accessed 11 Nov. 2019).

OECD (2011) 'Organisation for economic cooperation and development: Families are changing', [Online]

http://www.oecd.org/els/soc/incomeinequalityandpovertyrisinginmostoecdcountries.htm (Accessed 10 Nov. 2019).

OECD (2012) 'Organisation for economic cooperation and development: Perspectives on global development 2012 social cohesion in a shifting world', [Online] http://www.oecd.org/site/devpgd2012/49067839.pdf (Accessed 11 Nov. 2019).

Pasimeni, F. and Pasimeni, P. (2015) 'An Institutional Analysis of the Europe 2020 Strategy', Social Indicators Research, pp. 1-18.

Polidano, C., Tabasso, D., \& Tseng, Y. P. (2015) 'A second chance at education for early school leavers', Education Economics, Vol. 23, No. 3, pp. 358-375.

Putnam, R. D. (1995) 'Bowling alone: America's declining social capital', Journal of Democracy, Vol. 6, pp. 65-78. 
Putnam, R. D. (2001) Bowling alone: The collapse and revival of American community. New York, NY: Simon and Schuster.

Raffo, C. and Gunter, H. (2008) 'Leading schools to promote social inclusion: Developing a conceptual framework for analysing research, policy and practice', Journal of Education Policy, Vol. 23, pp. 397-414.

Ramsden, P. (2003) Learning to teach in higher education. Oxford, UK: Routledge.

Souto-Otero, M. S. and Whitworth, A. (2006) 'Equality in higher education in Spain and the UK: Mismatch between rhetoric and policy?' Higher Education Quarterly, Vol. 60, pp. 167186.

Spring, J. (2017) 'The intersection of cultures: Multicultural education in the United States and the global economy', Oxford, UK: Routledge.

Thorbecke, E. and Charumilind, C. (2002) 'Economic inequality and its socioeconomic impact', World Development, Vol. 30, pp. 1477-1495.

UNSDG4 (2015) 'Sustainable Development Goal 4: Ensure inclusive and quality education for all and promote lifelong learning'. [Online] http://www.un.org/sustainabledevelopment/education/ (Accessed 01 Dec. 2018).

Vladimirova, K. and Le Blanc, D. (2016) 'Exploring links between education and sustainable development goals through the lens of UN flagship reports', Sustainable Development, Vol. 24, No, 4, pp.254-271. 